\title{
Impact of Mental Health and Stress Level of Teachers to Learning Resource Development
}

OPEN ACCESS

Manuscript ID:

EDU-2021-09023702

Volume: 9

Issue: 2

Month: March

Year: 2021

P-ISSN: 2320-2653

E-ISSN: 2582-1334

Received: 30.01.2021

Accepted: 12.02.2021

Published: 01.03.2021

Citation:

Jimenez, Edward C.

"Impact of Mental

Health and Stress Level of Teachers to Learning Resource Development." Shanlax International Journal of Education, vol. 9, no. 2, 2021, pp. 1-11.

DOI:

https://doi.org/10.34293/ education.v9i2.3702

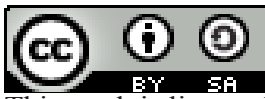

This work is licensed under a Creative Commons Attribution-ShareAlike 4.0 International License

\author{
Edward C. Jimenez \\ Education Program Supervisor, Department of Education \\ Schools Division of the City of Meycauayan, Bulacan, Philippines \\ https://orcid.org/0000-0001-6876-7935
}

\begin{abstract}
This study aimed at analyzing the mental health and stress level of teachers in the Schools Division in Central Luzon, Philippines. At the same time, it identified the relationship and impact of mental health and stress level of the teachers as regards learning resource development. The study employed a descriptive-correlation research design with the online survey as the primary data collection tool. The respondents came from the 25 elementary schools in Schools Division in Central Luzon. 205 teachers participated in the online survey using a simple random sampling technique. An adapted and modified questionnaire was used to gather data. For the statistical treatment of the study, the mean was used for the responses of the teachers and the relationship and impact; the study used Pearson-r and regression analysis.

The study found that in terms of mental health, the teachers experience less than once a week of sleeping problems. For social well-being, teachers experience them almost every day. For the things that bother them, the teachers were not bothered at all. The teachers also have positive mental health and for the aspect of bouncing back, they responded neutrally. In terms of stress level, the teachers revealed that they sometimes experience such a thing. For the learning resource development, the response of the teachers was "strongly agree." Also, there exists a low direct relationship between mental health level and the development of learning resources. To confirm the relationship, the regression analysis found that mental health significantly impacts the learning resource development of teachers. Based on the results above, the researcher provided some important recommendations for the study.
\end{abstract}

Keywords: Mental health, Stress level, Teacher, Learning resource development

\section{Introduction}

The mental health and stress level of teachers are two important factors that allow them to become holistic classroom managers and leaders. Teachers are the front lines of the Department of Education (DepEd) in delivering its curriculum, services, and skills mastery to the learners. Although schools are not yet ready to implement distance learning (Asio \& Bayucca, 2021), the delivery of learning must go on. They attend training and workshop and undergo technical assistance from mentors and experts to be well-equipped for school-related activities, become prepared in teaching, and evolve into holistic developers of the learners. This professional and personal context of teachers makes up their innate qualities in 21 st-century teaching. Putting them on the frontlines of the education system, the state must consider their physical, mental, social, and psychological well-being, and education officials must ensure that they have the necessary knowledge, cognitive perspective, skills enhancement, and technical competence to serve learners with different needs. Their mental understanding should be sound, and their level of stress must be tolerable. 
The mental health wellness of teachers provides learner's a positive learning and development experience through school-based mental health services. According to Cowan (2012), there is heightened urgency to advance school-based mental health and school psychologists' expertise as essential to providing quality, evidence-based services to teachers. In the same manner, stress management of teachers magnifies the result of managed pressures. However, based upon the study conducted by von der Embse et al. (2019), due to the increased pressure from test-based accountability practices, teachers have reported high levels of stress and burnout, which calls for stress interventions an important first step toward reducing negative outcomes. Results of the study indicated that the most effective interventions were in the mindfulness, behavioral, and cognitive-behavioral domains.

Public school teachers are confronted with numerous paperwork and workloads. According to DepEd Secretary Leonor Briones, not only the teachers are suffering from a heavy workload; everyone in government service is overworked and under immense pressure (Terrazola, 2018). This further proves that public school teachers are bombarded with work-related assignments such as reports, instructional materials, school designations and other related tasks apart from their usual sixhour teaching load every day. This work situation leads to the dwindling performance of teachers from its target, which is beyond Proficiency Level. Given this workload, actual teaching tasks are being sidelined by the multitude of other responsibilities and roles teachers play (David et al., 2019).

Learning resource (LR) development requires a lot of motivation and support to accomplish credible materials for learners of all schools in the Division. According to Jimenez (2020), there are ten (10) motivating factors that help teachers to develop learning resources. These findings proved that learning resource development adds value to teachers' professional development and overall satisfaction as employees and members of the DepEd (Asio \& Jimenez, 2020). They suggested that professional development, organizational culture, supervisory rapport, and overall satisfaction should promote organizational development among employees.
It is very important to find a suitable approach that emphasizes the delivery of strategic instruction to the ones catered by the curriculum, especially at this point (Sebastian, 2019). At present, teachers are left with uncertainty on how to proceed with the teaching and learning process amid the pandemic caused by coronavirus disease 2019 (COVID-19). With a bulk of work left undone (e.g. last quarter exam, computation of grades, issuance of cards, reading of forms, etc.) in the outgoing school year, teachers are awaiting the directive to process under the new normal of the education agency. This "new normal" prepares the teachers to be equipped with adaptive leadership and increased technological competence, which are primary and valuable skills to master. This global pandemic brought worries, fears, and uncertainties amongst teachers, which steered them out of people, work, and gatherings. However, this situation also taught teachers bravery, camaraderie, and unity to help, support, and control this global threat. Teachers need to have a clear mindset and psychological understanding to be prepared and ready for the new normal. According to Avci et al. (2017), teachers in primary school need work-related relationship, while secondary school teachers need autonomy. The study also mentioned that the needs or success, independence, and dominance are among the psychological needs which significantly predict perceived stress.

The main purpose of this study is to analyze the impact of mental health and stress levels of teachers on learning resource development. Also, it sought to find out the relationship between mental health, the stress level of teachers, and learning resource development. Furthermore, the study would also like to find out the impact of mental health and stress level of teachers on learning resource development.

The researcher would like to use the findings of this study in formulating management programs and interventions of school leaders in addressing their teachers' mental health and stress level in developing learning resources.

\section{Literature Review Mental Health}

Mental health, shame, and protective factors are gaining awareness in this generation. In the study 
conducted by Kotera et al. (2019), it found out that there was a significant correlation that exists between mental health and self-compassion, identified as an exploratory variable for mental health. Shame moderated the relationship between self-compassion and mental health. Integrating self-compassion training or program is suggested to help improve the students' mental health.

Mental health and mental illness are links to social adversity. According to Salerno (2016) in his study entitled "Effectiveness of Universal SchoolBased Mental Health Awareness Programs among Youth in the United States: A Systematic Review," although there was some level of improvement in students' mental health awareness, more research on the implementation of the said program is needed using randomized controlled trial design, and longterm follow-up implementation. The balancing of multiple opposing trends in the mental health service of practitioners and administrators determine the future course of mental health services in higher education institutions (Bonfiglio, 2016).

\section{Stress Level}

According to Cambridge Dictionary, stress is the great worry caused by a difficult situation or something that causes people headaches, minor pains, and sleeping difficulties. While stress is universal among students, the difference between stress symptoms and the effects on behavior is the coping mechanism of students. Self-reported perceived stress and sleep quantity were not significant predictors of daily calculated stress level. This means that daily-calculated stress and health behaviors were significant predictors of self-reported perceived stress (van Berkel \& Reeves, 2017).

Likewise, in the study conducted by Cook \& Babyak (2019) entitled "The Impact of Spirituality and Occupational Stress among Middle School Teachers" stressed out that teachers' spirituality scores (through Daily Spiritual Experience Scale) significantly predicted time-management stress and work-related stress. There should be adventurebased outdoor programs that afford opportunities to be away from daily challenges that reduce psychological stress levels and provide relief of physiological stress levels (Chang et al., 2019).
Teachers should be given ample space to be relieved from stress through coping strategies and improve themselves as indispensable catalysts of the academic environment. Like other professionals, teachers experience stress and use avoidance of coping strategies, affecting their performance in the workplace. It is important to recognize and address the harmful effects of stress on well-being and academic achievement, to avoid long-term problems in professional and personal life (Gustems-Carnicer et al., 2019).

\section{Learning Resource Development}

Teachers are the best audio-visual tools that DepEd could ever have. Teachers, aside from the challenges that they face in everyday work, the rigors of students managements and the mountain of paperwork, are also confronted with the task to exhibit positive work habits and high teaching performance (Jimenez, 2020). Creativity is a very important tool in pedagogy (Sebastian, 2019). Teachers are the best developers of learning resources because they can develop a set of wellfit instructional materials for the learners to attain the mastery of learning competencies (Jimenez, 2020). The development of e-learning resources is affected by changes that create challenges on the other hand to teachers. There should be three (3) categories in terms of organizational centralization of development; (1) decentralized, (2) centralized, and (3) highly centralized. Findings revealed that the majority of the institutions fitted the centralized or highly centralized categories. This suggests that it can inform decisions around the organization of e-learning resource development (O'Brien et al., 2019).

Decades of researches have shown that technological change in schools depends on multiple interrelated factors. Educational technology integration depends on the teachers' and school's readiness. Teachers' readiness to integrate educational technology depends on their perceived skills and beliefs, which carry formal and informal exchange among teachers (Petko et al., 2018). The use of remediation activities embedded in the learning resources should improve students' academic performance (Asio \& Jimenez, 2020). 


\section{Research Methodology}

\section{Research Design}

Since the main concern of the study was to identify the impact of mental health and stress level of teachers on learning resource development, this study used a quantitative research design, particularly the descriptive-correlational research method. In this study, the quantitative research approach in analyzing and understanding the relationship between mental health and the stress level of teachers was used.

\section{Respondents}

The participants of this study were the teachers of the 25 elementary schools in the Schools Division in Central Luzon for the school year 2020-2021.

\section{Distribution of Respondents}

\begin{tabular}{|c|c|c|}
\hline Cluster & $\begin{array}{c}\text { Total } \\
\text { Population }\end{array}$ & $\begin{array}{c}\text { Sample Size } \\
\text { Respondents }\end{array}$ \\
\hline A & 291 & 58 \\
\hline B & 222 & 44 \\
\hline C & 205 & 41 \\
\hline Total & $\mathbf{7 1 8}$ & $\mathbf{1 4 3}$ \\
\hline
\end{tabular}

A random sampling procedure was used by the researcher in the conduct of the study. The three (3) elementary clusters in the Schools Division in Central Luzon were selected as the respondents of the study. In computing the number of respondents per cluster, $20 \%$ of the total population size was employed to get the actual sample size population of respondents.

\section{Instrument of the Study}

In this particular study, the researcher adopted and modified an instrument. For the stress level, the Perceived Stress Scale developed by Chan \& La Greca, 2013 was used. On the other hand, for the mental health status of teachers, the researcher adopted the Mental Health Survey by LifeRisks (2018). And for the last part, the researcher developed the questionnaire for the LR Development. The said instrument underwent professional critiquing for validity and reliability. And before the administration of the actual survey, it was first pre-tested by other teachers who were not part of the study for any confusing and misinterpreted terms or words to further enhance the validity of the instrument.

\section{Data Analysis}

The gathered data was processed using Excel and the Statistical Packages for Social Sciences (SPSS) application for windows software (version 22.0). The following statistical tools were used in the study: mean for the mental health, stress level and learning resource development of teachers, Pearson-r for the relationships between mental health, stress level and learning resource development of teachers and regression analysis for the impact of mental health and stress level to learning resource development of teachers. The responses of the respondents were patterned on Likert Scales.

\section{Results}

This part presents the analysis \& interpretation of all the data gathered in this study by the problems presented in Research Questions. It investigated the impact of mental health and stress level of teachers on learning resource development in three (3) Cluster Schools. Likewise, it investigated the relationship of teachers' mental health, stress level, \& learning resource development.

Table 1: Mental Health of Teachers in terms of Sleep

\begin{tabular}{|l|c|l|}
\hline \multicolumn{1}{|c|}{ Items } & Mean & \multicolumn{1}{c|}{ Interpretation } \\
\hline $\begin{array}{l}\text { Cannot get to sleep } \\
\text { within } 30 \text { minutes }\end{array}$ & 2.13 & Less than once a week \\
\hline $\begin{array}{l}\text { Wake up in the } \\
\text { middle of the night } \\
\text { or early morning }\end{array}$ & 2.17 & Less than once a week \\
\hline $\begin{array}{l}\text { Have to get up to } \\
\text { use the bathroom }\end{array}$ & 1.63 & Less than once a week \\
\hline $\begin{array}{l}\text { Cannot breathe } \\
\text { comfortably }\end{array}$ & 2.37 & Less than once a week \\
\hline $\begin{array}{l}\text { Cough or snore } \\
\text { loudly }\end{array}$ & 2.31 & Less than once a week \\
\hline Feel too cold & 2.68 & Once or twice a week \\
\hline Feel too hot & 1.20 & Not during past month \\
\hline Have bad dreams & 1.31 & Not during past month \\
\hline Have pain & 1.26 & Not during past month \\
\hline Average Mean & $\mathbf{1 . 7 6}$ & Less than once a week \\
\hline
\end{tabular}

Legend: $1=$ Not during the past month (1.00-1.49)

$2=$ Less than once a week $(1.50-2.49)$

$3=$ Once or twice a week (2.50-3.49)

$4=$ Three or more times a week (3.50-4.00) 
Table 1 presents the evaluation of the teachers about mental health in terms of sleep. As shown from the table, item number 6, "Feel too cold," was rated the highest with an average mean of 2.68, while item number 7, "Feel too hot," was rated the lowest with an average mean of 1.20. The overall average mean was computed at 1.76 , which was verbally interpreted as "less than once a week," as shown in Table 1.

Table 2: Mental Health of the Teacher in terms of Well-being (A)

\begin{tabular}{|c|c|c|}
\hline Items & Mean & Interpretation \\
\hline Happy & 5.03 & Almost everyday \\
\hline Interested in life & 4.77 & Almost everyday \\
\hline Satisfied with life & 5.29 & Almost everyday \\
\hline $\begin{array}{l}\text { That you had something } \\
\text { important to contribute to } \\
\text { society }\end{array}$ & 4.75 & Almost everyday \\
\hline $\begin{array}{l}\text { That you belonged to a } \\
\text { community (like social } \\
\text { group, religion, or your } \\
\text { neighborhood) }\end{array}$ & 4.62 & Almost everyday \\
\hline $\begin{array}{l}\text { That our society is a good } \\
\text { place, or is becoming a } \\
\text { better place, for all people }\end{array}$ & 4.82 & Almost everyday \\
\hline $\begin{array}{l}\text { That our society is } \\
\text { becoming a better place } \\
\text { for people like you. }\end{array}$ & 4.80 & Almost everyday \\
\hline $\begin{array}{l}\text { That people are basically } \\
\text { good }\end{array}$ & 5.04 & Almost everyday \\
\hline $\begin{array}{l}\text { That the way our society } \\
\text { works make sense to you }\end{array}$ & 4.87 & Almost everyday \\
\hline $\begin{array}{l}\text { That you liked most parts } \\
\text { of your personality }\end{array}$ & 5.15 & Almost everyday \\
\hline $\begin{array}{l}\text { Good at managing the } \\
\text { responsibilities of your } \\
\text { daily life }\end{array}$ & 5.09 & Almost everyday \\
\hline $\begin{array}{l}\text { That you had warm and } \\
\text { trusting relationships with } \\
\text { others }\end{array}$ & 5.00 & Almost everyday \\
\hline $\begin{array}{l}\text { That you had experiences } \\
\text { that challenged you to } \\
\text { grow and become a better } \\
\text { person }\end{array}$ & 4.94 & Almost everyday \\
\hline $\begin{array}{l}\text { Confident to think or } \\
\text { express your own ideas } \\
\text { and opinions }\end{array}$ & 5.32 & Almost everyday \\
\hline
\end{tabular}

http://www.shanlaxjournals.com

\begin{tabular}{|l|c|l|}
\hline $\begin{array}{l}\text { That your life has a sense } \\
\text { of direction or meaning } \\
\text { to it }\end{array}$ & 5.33 & Almost everyday \\
\hline Average Mean & $\mathbf{4 . 9 9}$ & Almost everyday \\
\hline
\end{tabular}

Legend: $1=$ Never (1.00-1.49)

$2=$ Once or twice in the past month (1.50-2.49)

$3=$ About once a week (2.50-3.49)

$4=$ Two to three times per week (3.50-4.49)

$5=$ Almost every day (4.50-5.49)

$6=$ Everyday (5.50-6.00)

Table 2 presents the evaluation of teachers about mental health in terms of well-being (experienced). As shown in the table, item statement number 15, "That your life has a sense of direction or meaning to it," was rated the highest with an average mean of 5.33. In contrast, item statement number 5, "That you belonged to a community (like social group, religion, or your neighborhood)," was rated as the lowest with an average mean of 4.62. The overall average mean was computed at 4.99 with a verbal interpretation of "Almost every day."

\section{Table 3: Mental Health of the Teacher in terms} of Well-being (B)

\begin{tabular}{|l|c|c|}
\hline \multicolumn{1}{|c|}{ Items } & Mean & Interpretation \\
\hline $\begin{array}{l}\text { How often have you been } \\
\text { bothered by little interest or } \\
\text { pleasure in doing things }\end{array}$ & 1.74 & Several Days \\
\hline $\begin{array}{l}\text { How often have you been } \\
\text { bothered by feeling down, } \\
\text { depressed or hopeless }\end{array}$ & 1.53 & Several Days \\
\hline $\begin{array}{l}\text { How often have you been } \\
\text { bothered by trouble falling } \\
\text { sleep, staying asleep, or } \\
\text { sleeping too much }\end{array}$ & 1.57 & Several Days \\
\hline $\begin{array}{l}\text { How often have you been } \\
\text { bothered by feeling tired or } \\
\text { having little energy }\end{array}$ & 1.80 & Several Days \\
\hline $\begin{array}{l}\text { How often have you been } \\
\text { bothered by poor appetite or } \\
\text { overeating }\end{array}$ & 1.45 & Not at All \\
\hline $\begin{array}{l}\text { How often have you been } \\
\text { bothered by feeling bad } \\
\text { about yourself - or that } \\
\text { you're a failure or have let } \\
\text { yourself or your family } \\
\text { down. }\end{array}$ & 1.43 & Not at All \\
\hline
\end{tabular}




\begin{tabular}{|l|l|l|}
\hline $\begin{array}{l}\text { How often have you } \\
\text { been bothered by trouble } \\
\text { concentrating on things, such } \\
\text { as reading the newspaper or } \\
\text { watching television }\end{array}$ & 1.43 & Not at All \\
\hline $\begin{array}{l}\text { How often have you been } \\
\text { bothered by moving or } \\
\text { speaking so slowly that other } \\
\text { people could have noticed. } \\
\begin{array}{l}\text { Or, the opposite - being } \\
\text { restless that you have been } \\
\text { moving around a lot more } \\
\text { than usual. }\end{array}\end{array}$ & 1.26 & Not at All \\
\hline $\begin{array}{l}\text { How often have you been } \\
\text { bothered by thoughts that } \\
\text { you would be better off dead } \\
\text { or of hurting yourself in } \\
\text { some way }\end{array}$ & 1.12 & Not at All \\
\hline \multicolumn{1}{|c|}{ Average Mean } & $\mathbf{1 . 4 8}$ & Not at All \\
\hline
\end{tabular}

Legend: $1=$ Not at all (1.00-1.49)

$2=$ Several days (1-6 days) (1.50-2.49)

$3=$ More than half the days (7-10 days)

(2.50-3.49)

$4=$ Nearly Everyday (11-14 days) (3.50-4.00)

Table 3 presents the evaluation of teachers about mental health in terms of well-being (bothered). As can be seen from the table, item number 4, "How often have you been bothered by feeling tired or having little energy?" was rated as the highest with an average mean of 1.80 . In contrast, item number 9, "How often have you been bothered by thoughts that you would be better off dead or of hurting yourself in some way?" was rated as the lowest with a computed mean of 1.12 . The overall average mean was tabulated at 1.48 and verbally interpreted as "Not at All," as shown in Table 3.

Table 4: Mental Health of the Teacher in terms of Positive Mental Health

\begin{tabular}{|l|c|c|}
\hline \multicolumn{1}{|c|}{ Items } & Mean & Interpretation \\
\hline $\begin{array}{l}\text { In certain times, I usually } \\
\text { expect the best. }\end{array}$ & 3.92 & Agree \\
\hline $\begin{array}{l}\text { If something can go wrong } \\
\text { for me, it will. }\end{array}$ & 3.21 & Agree \\
\hline $\begin{array}{l}\text { I'm always optimistic } \\
\text { about my future. }\end{array}$ & 4.17 & Agree \\
\hline $\begin{array}{l}\text { I hardly ever expect things } \\
\text { to go my way. }\end{array}$ & 4.18 & Agree \\
\hline
\end{tabular}

\begin{tabular}{|l|c|c|}
\hline $\begin{array}{l}\text { I rarely count on good } \\
\text { things happening to me. }\end{array}$ & 3.33 & Neutral \\
\hline $\begin{array}{l}\text { Overall, I expect more } \\
\text { good things to happen to } \\
\text { me than bad. }\end{array}$ & 4.25 & Agree \\
\hline \multicolumn{1}{|c|}{ Average Mean } & $\mathbf{3 . 8 4}$ & Agree \\
\hline
\end{tabular}

Legend: 1 = Strongly Disagree (1.00-1.49)

$2=$ Disagree $(1.50-2.49)$

$3=\operatorname{Neutral}(2.50-3.49)$

$4=$ Agree (3.50-4.49)

$5=$ Strongly Agree $(4.50-5.00)$

Table 4 shows the mental health of teachers in terms of positive mental health as evaluated by the teacher. As can be seen from the table, item number 6, "Overall, I expect more good things to happen to me than bad," was rated as the highest with a weighted mean of 4.25 , while item number 2 , "If something can go wrong for me, it will" was rated as the lowest with a computed mean 3.21. The overall average mean was computed at 3.84 with a verbal interpretation of "Agree."

Table 5: Mental Health of Teachers in terms of Bouncing Back

\begin{tabular}{|l|c|c|}
\hline \multicolumn{1}{|c|}{ Items } & Mean & Interpretation \\
\hline $\begin{array}{l}\text { I tend to bounce back } \\
\text { quickly after hard times. }\end{array}$ & 3.73 & Agree \\
\hline $\begin{array}{l}\text { I have a hard time making } \\
\text { it through stressful events. }\end{array}$ & 2.77 & Neutral \\
\hline $\begin{array}{l}\text { It does not take me long to } \\
\text { recover from stressful }\end{array}$ & 3.39 & Neutral \\
\hline $\begin{array}{l}\text { It is hard for me to snap } \\
\text { back when something bad }\end{array}$ & 2.65 & Neutral \\
\hline $\begin{array}{l}\text { I usually come through } \\
\text { difficult times with little } \\
\text { trouble. }\end{array}$ & 2.97 & Neutral \\
\hline $\begin{array}{l}\text { I tend to take a long time } \\
\text { to get over set-backs in my } \\
\text { life. }\end{array}$ & 2.61 & Neutral \\
\hline \multicolumn{1}{|c|}{ Average Mean } & $\mathbf{3 . 0 2}$ & Neutral \\
\hline
\end{tabular}

Legend: $1=$ Strongly Disagree (1.00-1.49)

$2=$ Disagree $(1.50-2.49)$

$3=$ Neutral $(2.50-3.49)$

$4=$ Agree (3.50-4.49)

$5=$ Strongly Agree $(4.50-5.00)$

Table 5 presents the evaluation of the teachers in mental health in terms of bouncing back. The table 
shows that item number 1, "I tend to bounce back quickly after hard times," was rated as the highest with an average mean of 3.73. In contrast, the lowest item statement was item number 6, "I tend to take a long time to get over set-backs in my life," with an average mean of 2.61 which had a verbal interpretation of agree. The overall average mean was tabulated at 3.02 and verbally interpreted as "Neutral" as shown in Table 5.

\section{Table 6: Stress Level of Teachers}

\begin{tabular}{|l|l|l|}
\hline \multicolumn{1}{|c|}{ Items } & Mean & Interpretation \\
\hline $\begin{array}{l}\text { In the last month, how } \\
\text { often have you been upset } \\
\text { because of something that } \\
\text { happened unexpectedly? }\end{array}$ & 3.00 & Sometimes \\
\hline $\begin{array}{l}\text { In the last month, how } \\
\text { often have you felt that you } \\
\text { were unable to control the } \\
\text { important things in your } \\
\text { life? }\end{array}$ & 2.83 & Sometimes \\
\hline $\begin{array}{l}\text { In the last month, how often } \\
\text { have you felt nervous and } \\
\text { stressed? }\end{array}$ & 3.19 & Sometimes \\
\hline $\begin{array}{l}\text { In the last month, how often } \\
\text { have you felt confident } \\
\text { about your ability to handle } \\
\text { your personal problems? }\end{array}$ & 3.40 & Sometimes \\
\hline $\begin{array}{l}\text { In the last month, how often } \\
\text { have you felt that things } \\
\text { were going your way? }\end{array}$ & 3.24 & Sometimes \\
\hline $\begin{array}{l}\text { In the last month, how often } \\
\text { have you found that you } \\
\text { could not cope with all the } \\
\text { things that you had to do? }\end{array}$ & 2.65 & Sometimes \\
\hline $\begin{array}{l}\text { In the last month, how } \\
\text { often have you been able to } \\
\text { control irritations in your } \\
\text { life? }\end{array}$ & 3.25 & Sometimes \\
\hline $\begin{array}{l}\text { In the last month, how often } \\
\text { have you felt that you were } \\
\text { on top of things? }\end{array}$ & 2.89 & Sometimes \\
\hline $\begin{array}{l}\text { In the last month, how often } \\
\text { bave you been angered }\end{array}$ & 2.77 & Sometimes \\
\hline
\end{tabular}

\begin{tabular}{|l|c|c|}
\hline $\begin{array}{l}\text { In the last month, how often } \\
\text { have you felt difficulties } \\
\text { were piling up so high that } \\
\text { you could not overcome } \\
\text { them? }\end{array}$ & 2.75 & Sometimes \\
\hline \multicolumn{1}{|c|}{ Average Mean } & $\mathbf{3 . 0 0}$ & Sometimes \\
\hline
\end{tabular}

Legend: $1=$ Never (1.00-1.49)

$$
\begin{aligned}
& 2=\text { Almost Never }(1.50-2.49) \\
& 3=\text { Sometimes }(2.50-3.49) \\
& 4=\text { Fairly Often }(3.50-4.49) \\
& 5=\text { Very Often }(4.50-5.00)
\end{aligned}
$$

Table 6 reveals the highest and lowest ranking of the stress levels as evaluated by the teachers. Item number 4, "In the last month, how often have you felt confident about your ability to handle your problems?" ranked first with a computed mean of 3.40. In contrast, item number 6, "In the last month, how often have you found that you could not cope with all the things that you had to do?" was rated the lowest with a computed average mean of 2.65. The overall average mean was computed at 3.00. All items were verbally interpreted as "Sometimes."

Table 7: Learning Resource Development

\begin{tabular}{|l|c|c|}
\hline \multicolumn{1}{|c|}{ Items } & Mean & Interpretation \\
\hline $\begin{array}{l}\text { The Learning Resources } \\
\text { (LRs) developed are } \\
\text { anchored to DepEd } \\
\text { Learning Competencies }\end{array}$ & 4.63 & Strongly Agree \\
\hline $\begin{array}{l}\text { The LRs used by the } \\
\text { learners effectively helped } \\
\text { them to master Learning } \\
\text { Competencies. }\end{array}$ & 4.60 & Strongly Agree \\
\hline $\begin{array}{l}\text { The materials developed } \\
\text { assisted you to deliver the } \\
\text { lesson/s easier. }\end{array}$ & 4.65 & Strongly Agree \\
\hline $\begin{array}{l}\text { The level of materials } \\
\text { developed is within the } \\
\text { target needs of the learners }\end{array}$ & 4.61 & Strongly Agree \\
\hline $\begin{array}{l}\text { The learning activities } \\
\text { provided in the materials } \\
\text { are user-friendly. }\end{array}$ & 4.61 & Strongly Agree \\
\hline \multicolumn{1}{|c|}{ Average Mean } & $\mathbf{4 . 6 2}$ & Strongly Agree \\
\hline
\end{tabular}

Legend: 1 = Strongly Disagree (1.00-1.49)

$$
\begin{aligned}
& 2=\text { Disagree }(1.50-2.49) \\
& 3=\text { Neutral }(2.50-3.49) \\
& 4=\text { Agree }(3.50-4.49) \\
& 5=\text { Strongly Agree }(4.50-5.00)
\end{aligned}
$$


Table 7 presents the evaluation of the teachers about their learning resource development skills. The table shows that item number 3, "The materials developed assisted you to deliver the lesson/s easier," was rated the highest with a computed mean of 4.65. In contrast, item number 2, "The LRs used by the learners effectively helped them master Learning Competencies," was rated the lowest with a computed weighted mean of 4.60. As shown in Table 7, all item statements were tabulated and had an overall weighted mean of 4.62 and were verbally interpreted as "Strongly Agree."

Table 8: Correlation Matrix between Mental Health, Stress Level, and LR Development of Teachers

\begin{tabular}{|l|l|c|c|c|}
\hline & & Mental Health & Stress Level & LR Development \\
\hline \multirow{4}{*}{ Mental Health } & Pearson-r & 1 & & \\
\cline { 2 - 5 } & Sig. (2 Tailed) & & & \\
\cline { 2 - 5 } & $\mathrm{N}$ & & & \\
\hline \multirow{4}{*}{ Stress Level } & Pearson-r & $.151^{*}$ & 1 & \\
\cline { 2 - 5 } & Sig. (2 Tailed) & .031 & & \\
\cline { 2 - 6 } & $\mathrm{N}$ & 204 & & \\
\hline \multirow{3}{*}{ LR Development } & Pearson-r & $.201^{*}$ & -.077 & \\
\cline { 2 - 6 } & Sig. (2 Tailed) & .004 & .272 & \\
\cline { 2 - 6 } & $\mathrm{N}$ & 204 & 204 & \\
\hline
\end{tabular}

* Significant at .05 Alpha Significance Level

The table shows the relationship between mental health level and stress level of teachers and the learning resource development of teachers. It can be gleaned that mental health level has a low direct relationship with the learning resource development. This is because the mental health level obtained a Pearson Correlation of .201, which has a corresponding probability value of .004 , lower than the alpha significance level of .05 . On the other hand, stress level did not produce enough results to attain a significant relationship to learning resource development. It only got a Pearson Correlation of -.077 , which corresponds to a probability value of .272 , which is higher than the alpha significance level of .05 .

Table 9: Regression Analysis on the Impact of Mental Health and Stress Level to Learning Resource Development of Teachers

\begin{tabular}{|c|c|c|c|c|c|}
\hline \multirow{2}{*}{ Model } & \multicolumn{2}{|c|}{ Unstandardized Coefficients } & Standardized Coefficients & \multirow{2}{*}{ t } & \multirow{2}{*}{ Sig. } \\
\cline { 2 - 5 } & $\mathbf{B}$ & Std. Error & Beta & 7.459 & .000 \\
\hline (Constant) & 3.486 & .467 & & $3.128^{*}$ & .002 \\
\hline Mental Health & .473 & .151 & .217 & -1.584 & .115 \\
\hline Stress Level & -.098 & .062 & -.110 & \\
\hline
\end{tabular}

Note: $\mathrm{F}(2,201)=5.523, \mathrm{p}=.005 ; \mathrm{R}^{2}=.052$

To determine which variable significantly impacts the learning resource development of the teachers, a regression analysis was done. Table 9 showed the regression analysis result. It can be seen that the mental health level of the teachers significantly impacts the learning resource development with a $\mathrm{B}$-coefficient result that is lower the significant alpha level of .05. This means that mental health level is a significant determinant of the learning resource development of teachers. Furthermore, based on the obtained B coefficient, it could be deduced that every unit increase in the learning resource development of teachers generates a 467 increase in their mental health level. In general, the stress level of teachers also correlated with their learning resource development level but not to a significant extent. This means that stress level also affects the learning resource development of teachers. 


\section{Discussion}

The identification of the significant correlates of teachers' mental health, stress level, and learning resource development has been the major concern of this study. The independent variables, mental health and stress level of teachers, were correlated with the dependent variable, the teachers' learning resource development.

According to Wilson \& Stith-Russell, (2010) the relationship between emotional health and academic achievement focuses on how the emotional wellbeing of students is directly related to how well a student performs in school while also addressing numerous challenges. Proper selection of intervention programs such as strategies for self-regulation of emotions and learning behaviors, fostering friendships, and supporting academic achievement should be related to positive mental health (AskellWilliams \& Lawson, 2015).

The result of the research conducted proves the significant impact of mental health on the learning resource development of teachers. This is similar to the study conducted by Vander Lind (2017), which emphasized how mental illness may negatively affect students' success and degree of persistence which means that there should be increased mental health concerns to students and help them learn and succeed. This is supported by the study of Cramer and Olivo (2016) entitled "Effects of a Culturally Adapted Social-Emotional Learning Intervention Program on Students' Mental Health," where they found out that learning intervention affects students' mental health. She stressed that student reports of social validity suggest high levels of intervention acceptability and relevance.

\section{Conclusion}

Based on the results of the study, the following conclusions were made:

1. In terms of the mental health status, teachers have trouble sleeping less than once a week; almost every day, teachers' well-being is often experienced and at the same time not at all bothered; teachers also have a positive outlook for mental health and in terms of bouncing back they are neutral.
2. In the context of stress level, teachers sometimes experience it.

3. For the learning resource development of teachers, they strongly agree that they were significantly anchored, helped and assisted.

4. There is a low direct relationship between mental health status and the learning resource development of teachers. On the other hand, stress levels did not exhibit enough to attain a significant relationship.

5. To confirm the relationship, regression analysis further showed that the mental health status of teachers significantly impacts the learning resource development of teachers.

\section{Recommendation}

In the light of the conclusions drawn, the following recommendations are at this moment offered by the researcher:

1. Teachers should maintain a healthy wellness lifestyle, particularly 7 to 9 hours of sleep, to have a healthy mind and body.

2. Teachers may engage in wellness programs (e.g., yoga, Zumba, etc.) to better improve their mental attitude towards work.

3. Teachers should develop tolerating gestures and reframed self-management skills to better handle challenge situations.

4. Continuous development of quality, accessible, contextualized, and timely learning resources based on the latest trends in education, particularly this time of new normal, is encouraged.

5. School heads should include stress management simulations during SLAC or INSET that will test the behavioral competence of teachers in extracting their capacity to handle changes or stress in the workplace.

6. Schools should establish a teachers' service center (TSC) to provide psychosocial assistance and mental health awareness.

7. School heads and educational leaders should have concrete programs on wellness, fitness, and lifestyle well-being of teachers and personnel to maintain a healthy lifestyle and positive mind set at work. 
8. Education Program Supervisors may use this study as a springboard to develop their programs and adopt this strategy to develop learning resources fastened by higher-order thinking skills content or activity-lesson-assessment (ALA) for the higher academic performance of learners.

\section{References}

Asio, John Mark R., and E.C. Jimenez. "Professional Development, Organizational Climate, Supervisory Rapport and Overall Satisfaction of Employees: An Attitudinal Study." International Journal of Scientific Research in Multidisciplinary Studies, vol. 6, no. 4, 2020, pp. 34-40.

Asio, John Mark R., and Edward C. Jimenez. "Effect of Remediation Activities on Grade Pupils' Academic Performance in Technology and Livelihood Education (TLE)." Pedagogical Research, vol. 5, no. 4, 2020.

Asio, John Mark R., and Erin E. Riego de Dios. "The College Students' Perspective on what makes an Educator Well-qualified." Journal of Pedagogical Research, vol. 3, no. 3, 2019, pp. 126-138.

Asio, John Mark R., and Shallimar A. Bayucca. "Spearheading Education during the COVID-19 Rife: Administrators' Level of Digital Competence and Schools' Readiness on Distance Learning." Journal of Pedagogical Sociology and Psychology, vol. 3, no. 1, 2021, pp. 19-26.

Askell-Williams, Helen, and Michael J. Lawson. "Relationships between Students' Mental Health and their Perspectives of Life at School." Health Education, vol. 115, no. 3-4, 2015, pp. 249-268.

Avci, Ahmet, et al. "Psychological Needs as the Predictor of Teachers' Perceived Stress Levels." Journal of Education and Training Studies, vol. 5, no. 4, 2017, pp. 154-164.

Bonfiglio, Robert A. "Anticipating the Future of Mental Health Needs on Campus." New Directions for Student Services, 2016, pp. 97-104.
Chan, Sherilyn F., and Annette M. La Greca. "Perceived Stress Scale (PSS)." Encyclopedia of Behavioral Medicine, edited by Marc D. Gellman and J. Rick Turner, Springer, 2013.

Chang, Yun, et al. "The Impact of Short-term Adventure-based Outdoor Programs on College Students' Stress Reduction." Journal of Adventure Education and Outdoor Learning, vol. 19, 2019, pp. 67-83.

Cook, Kenny L., and Andrew T. Babyak. "The Impact of Spirituality and Occupational Stress among Middle School Teachers." Journal of Research on Christian Education, vol. 28, no. 2, 2019, pp. 131-150.

Cowan, Katherine C. "Mental Health Awareness Month \& Speak Up for Kids." Communique, vol. 40, no. 6, 2012, pp 28-29.

Cramer, Kristine, M., and Sara Castro-Olivo. "Effects of a Culturally Adapted SocialEmotional Learning Intervention Program on Students' Mental Health." Contemporary School Psychology, 2016, pp. 118-129.

David, Clarissa C., et al. "Pressures on Public School Teachers and Implications on Quality." Philippine Institute for Development Studies Policy Notes, no. 2019-1, 2020.

Gustems-Carnicer, Jose, et al. "Stress, Coping Strategies and Academic Achievement in Teacher Education Students." European Journal of Teacher Education, vol. 42, no. 3, 2019, pp. 375-390.

Jimenez, Edward C., and Frie and Csee. "Motivating Factors of Teachers in Developing Supplementary Learning Materials (SLMs)." International Journal of Advanced Research, vol. 8, no. 5, 2020, pp. 108-113.

Jimenez, Edward C. "Contextualized E-Learning Resource: A Tool for Stronger Academic Platform." International Journal of Case Studies in Business, IT, and Education, vol. 4, no. 2, 2020, pp. 110-116.

Jimenez, Edward C. "Emotional Quotient, Work Attitude and Teaching Performance of Secondary School Teachers." Journal of Pedagogical Sociology and Psychology, vol. 2, no. 1, 2020, pp. 25-35. 
Kotera, Yasuhiro, et al. "Mental Health of UK University Business Students: Relationship with Shame, Motivation and Selfcompassion." Journal of Education for Business, vol. 94, no. 1, 2019, pp. 11-20.

Liferisks, https://liferisksph.wixsite.com/liferisksph

O'Brien, Ray, et al. "The Centralisation of Elearning Resource Development within the New Zealand Vocational Tertiary Education Sector." Australasian Journal of Educational Technology, vol. 35, no. 5, 2019, pp. 95-110.

Petko, Dominic, et al. "The Interplay of School Readiness and Teacher Readiness for Educational Technology Integration: A Structural Equation Model." Computers in the Schools, vol. 35, no. 1, 2018, pp. 1-18.

Salerno, John P. "Effectiveness of Universal School-Based Mental Health Awareness Programs among Youth in the United States: A Systematic Review." Journal of School Health, vol. 86, no. 12, 2016, pp. 922-931.
Sebastian, Mar Florence DC. "Using Songs as Springboard to Teaching Poetry and Narratives towards Improved Comprehension." International Journal of Academic and Applied Research, vol. 4, 2020, pp. 72-78.

Terrazola, Vanne Elaine. "DepEd, DOH to Address Teacher Suicides" Manila Bulletin, 2018.

van Berkel, Kelly, and Brenda Reeves. "Stress among Graduate Students in Relation to Health Behaviors." College Student Journal, vol. 51, no. 4, 2017, pp. 498-510.

VanderLind, Ren. "Effects of Mental Health on Student Learning." The Learning Assistance Review, vol. 22, no. 2, 2017, pp. 39-57.

von der Embse, Nathaniel, et al. "Teacher Stress Interventions: A Systematic Review." Psychology in the Schools, vol. 56, no. 8, 2019, pp. 1328-1343.

Wilson, Carolyn H, and Lafawndra Stith-Russell. The Relationship of High School Students in Inclusive Settings: Emotional Health and Academic Achievement, 2010.

\section{Author Details}

Edward C. Jimenez, Education Program Supervisor, Department of Education, Schools Division of the City of Meycauayan, Bulacan, Philippines, Email ID: edward.jimenez@deped.gov.ph 